\title{
SPATIAL USE OF RODENTS (RODENTIA: MAMMALIA) HOST BODY SURFACE BY ECTOPARASITES
}

\author{
BITTENCOURT, E. B. and ROCHA, C. F. D. \\ Setor de Ecologia, Instituto de Biologia, Universidade do Estado do Rio de Janeiro, Rua São Francisco Xavier, 524, \\ Maracanã, CEP 20550-019, Rio de Janeiro, RJ, Brazil \\ Correspondence to: Carlos Frederico Duarte Rocha, Setor de Ecologia, Instituto de Biologia, Universidade do \\ Estado do Rio de Janeiro, Rua São Francisco Xavier, 524, Maracanã, CEP 20550-019, Rio de Janeiro, \\ RJ, Brazil, e-mail: cfdrocha@uerj.br \\ Received January 9, 2001 - Accepted May 22, 2001 - Distributed August 31, 2002
}

(With 2 figures)

\begin{abstract}
We studied the ectoparasite and the Amblyopinini beetle fauna associated with four small mammal species of the Atlantic Rainforest of Ilha Grande, an island located off the southern Rio de Janeiro State Coast, Southeastern Brazil, analyzing to what extent the parasites were specific to each region of the host body. During the study, a total of 90 individual rodents were captured: 61 Proechimys iheringi Thomas, 1911 (Echymyidae), 22 Sciurus aestuans (Thomas, 1901) (Sciuridae), 4 Oxymycterus sp. (Waterhouse, 1837), and 2 Nectomys squamipes (Brants, 1827) (Sigmodontinae). The data showed that the ectoparasites and Amblyopinini on some rodent hosts in Ilha Grande tend to prefer particular host body sites, and that some ectoparasite species sites may overlap owing to their inaccessibility to the host.
\end{abstract}

Key words: small mammal, parasitim, ectoparasites, Atlantic Rainforest, rodent.

\section{RESUMO}

\section{Uso da superfície do corpo de hospedeiros roedores (Rodentia: Mammalia) por ectoparasitos}

Estudamos a fauna de ectoparasitos e besouros Amblyopinini associada a quatro espécies de pequenos mamíferos da Mata Atlântica da Ilha Grande, localizada no sul do Estado do Rio de Janeiro, Sudeste do Brasil, analisando em que extensão os ectoparasitos seriam específicos de cada região do corpo do hospedeiro. Durante o estudo capturamos um total de 90 roedores: 61 Proechimys iheringi Thomas, 1911 (Echymyidae), 22 Sciurus aestuans (Thomas, 1901) (Sciuridae), 4 Oxymycterus sp. (Waterhouse, 1837) e 2 Nectomys squamipes (Brants, 1827) (Sigmodontinae). Os dados mostraram que os ectoparasitos e os Amblyopinini encontrados vivendo nos hospedeiros roedores da Ilha Grande apresentam preferência por algumas áreas específicas do corpo do hospedeiro. Contudo, algumas espécies de ectoparasitos podem se sobrepor em alguns sítios que utilizam, aparentemente devido à limitação de acesso a esses sítios pelos hospedeiros, reduzindo sua remoção e aumentando a chance de que ali ocorram.

Palavras-chave: pequenos mamíferos, parasitismo, ectoparasitas, Mata Atlântica, roedores. 


\section{INTRODUCTION}

The space use pattern of organisms in the environment and microhabitat vary between species and is affected by biotic and abiotic factors which in turn depend on the scale of the organism considered (Marshall, 1981; Guimarães \& Papavero, 1999). For example, for an arthropod ectoparasite, the host surface constitutes the habitat, and the mode of occupation will depend on the intrinsic and extrinsic factors affecting the ectoparasite on that environmental scale (Marshall, 1981).

In large farm animals (cows), identification of preferred sites used by ticks and parasitic flies is relatively advanced. Studies of Boophilus microplus (Canestrini, 1878) and Amblyomma cajannense (Fabricius, 1787) ticks (Ixodidae: Parasitiformes) living on cows found no significant differences in space use on host surface between larvae, nymphs, and adults (Serra-Freire \& Cunha, 1987; Serra-Freire et al., 1995).

Conversely, information in the literature on patterns of spatial use of bodies of small mammals by their ectoparasites is meager (e.g., Castro $e t$ al., 1990, 1995, 1996a, 1996b; Cicchino \& Castro, 1994; Pereira, 1994). These studies generally by include only drawings of preferred oviposition sites for some louse species such as Hoplopleura reducta Ferris, 1921 - Hoplopleuridae: Anoplura (Castro et al., 1990); H. neotomydis Castro et al., 1995 - Hoplopleuridae: Anoplura (Castro et al., 1995); H. chelemydis Castro et al., 1996 Hoplopleuridae: Anoplura (Castro et al., 1996a); Trymenopon hispidum (Burmeister, 1838) Trimenoponidae: Mallophaga, Gyropus ovalis Burmeister, 1838, Gliricola procelli (Schrank, 1781)Gyropidae: Mallophaga and Pterophthirus imitans Werneck, 1942 - Hoplopleuridae: Anoplura (Castro et al., 1996b) and Gyropus parvus (Ewing, 1924), and Phtheiropoios rionegrensis Cicchino \& Castro, 1994 - Gyropidae: Mallophaga (Cicchino \& Castro, 1994). The only other information available includes a report or small mammal body regions on which were found larvae of Metacuterebra spp. Diptera: Cuterebridae (Pereira, 1994).

The relative lack of information on patterns of the space use may indicate the intrinsic difficulty in both identifying the ectoparasit, and observing its natural position on the host.
In this paper, we present the results of a study of space use of some ectoparasites on rodent body surfaces in the Atlantic Rainforest of Ilha Grande, and the differences found in site preferences on a host body by each species. Specifically, we addressed the following questions: (1) Do ectoparasites have preferred host sites? (2) Do syntopic ectoparasite species overlap on occupied sites?

\section{MATERIAL AND METHODS}

\section{Study area}

The study was carried out in four Atlantic rainforest areas near Vila Dois Rios $\left(23^{\circ} 11^{\prime} \mathrm{S}\right.$, $44^{\circ} 12^{\prime} \mathrm{W}$ ), a village on Ilha Grande, located approximately $150 \mathrm{~km}$ south of the city of Rio de Janeiro (Fig. 1). The Atlantic Rainforest covering this island shows different levels of regeneration following century-old anthropogenic disturbances (including intensive coffee, corn, and sugar farming), stopped only by the transformation of the area into a State Park (Araújo \& Oliveira, 1988). Some remnants of primary forest (where only some selected cutting appears to have occurred) can still be found in the most inaccessible central areas of the island. Annual area rainfall is about $2200 \mathrm{~mm}$ (Estação Meteorológica, Central Nuclear de Angra dos Reis [NUCLEN], 1996-1999) and mean annual temperature is about $23^{\circ} \mathrm{C}$. In the study area, sampling was done in primary and secondary forests.

\section{Collecting methods and analysis}

Rodents were trapped from March 1996 throughout April 1997 in one area of primary forest (Jararaca), two of secondary forests (Caxadaço and Mãe D'água), and in a fourth Vila Dois Rios. In each area we set up 70 live traps (Young and Sherman) along ten parallel transects (200 m long each one) in a 2 ha area with $20 \mathrm{~m}$ separating every trap from the others, totaling 7474 trap-night. The traps, baited with bananas, remained opened from afternoon to the next morning when they were checked. Prior to sampling, we specified 12 body surface regions to the systematically sampled for ectoparasites. These were: head, ear, neck (dorsal and ventral regions), dorsum, lateral regions, belly, hind feet (internal and external regions), forefeet (internal and external regions), tail base (tail insertion on body), and tail. 


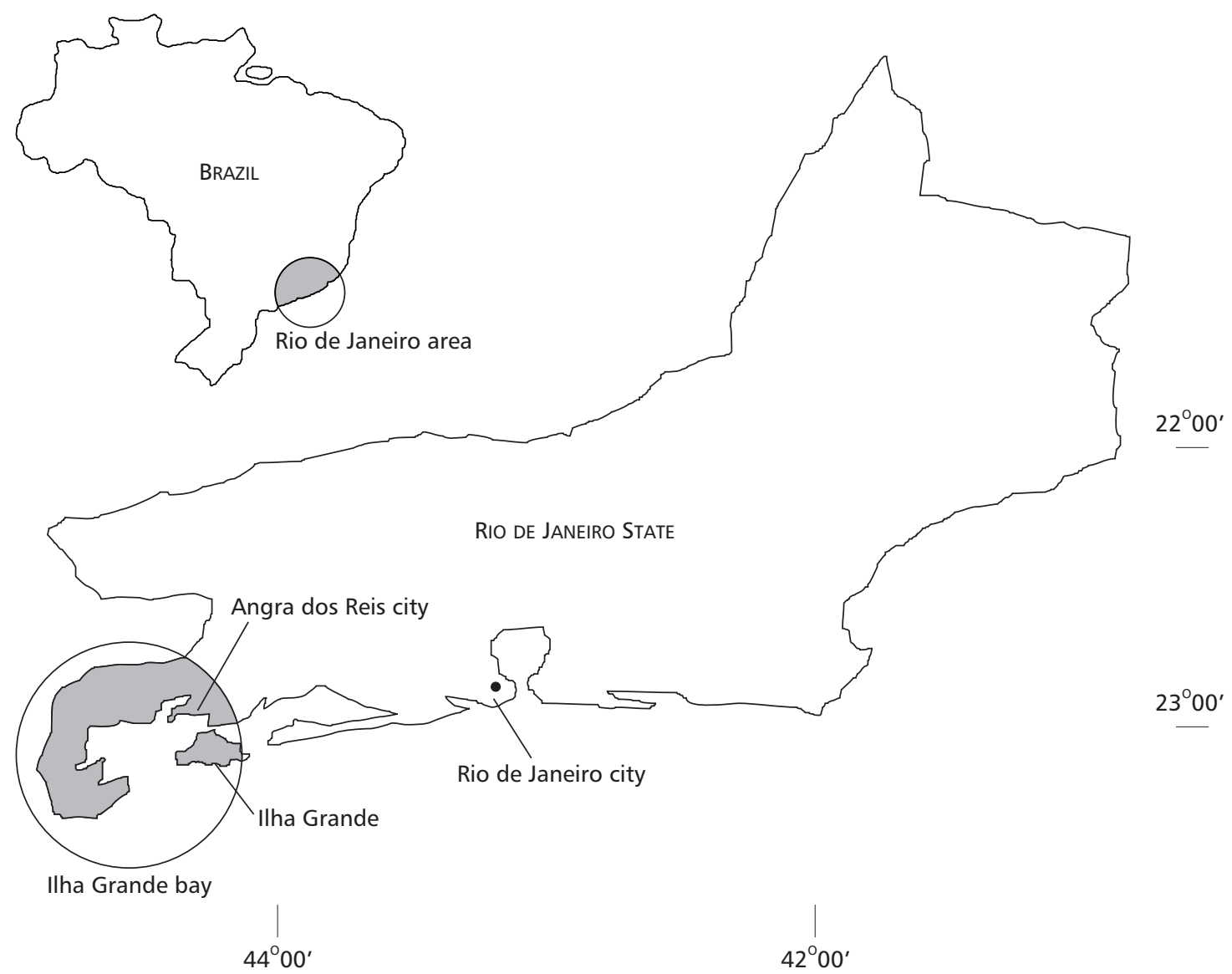

Fig. 1 - Localization of the study site on Ilha Grande in the state of Rio de Janeiro Southeastern, Brazil.

TABLE 1

Spatial niche breadth values $\left(B_{i j}\right)$ calculated for the ectoparasite species and the coleopteran Amblyopinus sp. found on the body surface of the rodent host Proechimys iheringi in the Atlantic Rainforest of Ilha Grande.

\begin{tabular}{|l|c|}
\hline \multicolumn{1}{|c|}{ Species } & Spatial niche breadth $\left(\boldsymbol{B}_{i j}\right)$ \\
\hline Ixodes sp. (larvae and nymphs) & 1.00 \\
\hline Tur sp. & 1.92 \\
\hline Tur turki & 2.13 \\
\hline Gliricola porcelli & 1.53 \\
\hline Gyropus lineatus & 1.85 \\
\hline Pterophthirus wernecki & 1.22 \\
\hline Amblyopinus sp. & 1.00 \\
\hline
\end{tabular}


Each rodent captured was marked (to avoid sampling the same individual twice) by using an earperforation code (Bergallo, 1995). Each individual host was anesthetized inside a plastic bag containing a piece of cotton soaked with sulfuric ether. Each region body surface region was systematically checked and the ectoparasites removed by combing the hair with a fine-tooth comb. After ectoparasite removal, they were placed in an individual vial, and the same sampling procedure was carried out on another body region. We used each plastic bag only once, to avoid contamination between hosts. By sampling each host area, we recorded species-specific microhabitats of both ectoparasites and some coleopteran insects of the Staphylinidae family Amblyopinini tribe (genera Ablyopinus Solsky, 1875 and Amblyopinodes Seevers, 1955). These beetles will not be treated here as ectoparasites because their function on the host body is still unclear (Ashe \& Timm, 1987a, 1987b; Timm \& Ashe, 1988). In our samplings and analysis, we also excluded Siphonaptera as it constitutes a group of ectoparasite species which move rapidly on the host body (rather than being attached or stationary, as are the others), preventing preferred site identification. As a safeguard, we sampled ectoparasites and Amblyopinini from each host only once (standardized as its first capture). For each ectoparasite or amblyopine species, we estimated the number of individuals on each body region and calculated the spatial occupation niche (Pianka, 1973, 1986) according to the spectrum of microhabitats used (body regions) by the species to this end, we used the Simpson index (Simpson, 1949), $B_{i j}=1 / \Sigma P_{i}^{2}$ in which $P_{i}$ is the proportion of individuals of the $i$ species associated with each body region of the host. To measure the overlap of preferred sites (microhabitats) used by syntopic ectoparasite and amblyopine species on a host species, we used the niche overlap equation (Pianka, 1986) first proposed by MacArthur and Levins (MacArthur \& Levins, 1967):

$$
O_{\mathrm{jk}}=P_{\mathrm{ij}} \cdot P_{\mathrm{ik}} / \sqrt{\Sigma P_{\mathrm{ij}}^{2} \cdot \Sigma P_{\mathrm{ik}}^{2}}
$$

in which $P_{i j}$ and $P_{i k}$ are respectively the proportion of individuals of the $j$ and $k$ species associated with the $i$ region.

\section{RESULTS}

During the study, a total of 90 rodents were caught: 61 Proechimys iheringi Thomas, 1911
(Echymyidae), 22 Sciurus aestuans (Thomas, 1901) (Sciuridae), four Oxymycterus sp. (Waterhouse, 1837), and two Nectomys squamipes (Brants, 1827) (Sigmodontinae).

However, since we used only the first capture of each individual in our analysis and that we also included only those individuals of which we were sure that field manipulation had not affected the ectoparasite or Amblyopinini positioning and density estimates, data analysis was restricted to 33 individuals (14 P. iheringi, 13 S. aestuans, 4 Oxymycterus sp., and 2 N. squamipes).

We found different arthropod species on each of these rodents, although some of them were treated only at the genus level because either they were immature or represented some undescribed species (but relatively easy to recognize as different species due to marked differences in setal morphology and number). Most of the data is on P. iheringi, the most frequently captured rodent species and the easiest host to manipulate without information loss.

On $P$. iheringi we found six ectoparasite species [Pterophthirus wernecki Guimarães, 1950 Hoplopleuridae: Anoplura; Gliricola porcelli (Schrank, 1781), Gyropus lineatus Neumann, 1912 - Gyropidae: Mallophaga; Tur turki Fonseca, 1959, Tur sp. Laelapidae: Parasitiformes; larvae and nymphs of the Ixodes sp. Latreille, 1795 - Ixodidae: Parasitiformes] and one amblyopine species (Amblyopinus sp.) which occupied different portions of the host body (Fig. 2). Table 1 shows the spatial niche breadth on the $P$. iheringi body for each ectoparasite and amblyopine beetle species. Ixodes sp. and Amblyopinus sp. were markedly specific to body regions they occupied and presented the smallest estimated value for spatial niche breadth (Table 1). Ixodes sp. occurred only on the internal region of the hind foot whereas Amblyopinus sp. was found only on the dorsal base of the tail (Fig. 2). Conversely, the mite Tur turki had the largest spatial niche breadth, and was found in four body regions (dorsal and ventral neck; dorsum; and external region of hind foot) (Table 1, Fig. 2). Table 2 shows the spatial niche overlap of the arthropods on the body of $P$. iheringi. Amblyopinus sp. and Ixodes sp. did not overlap $\left(O_{j k}=0\right)$ in spatial use with any other ectoparasite species (Table 2).

However, for the other species the spatial niche overlap was relatively high $\left(O_{j k}\right.$ varying from 0.978 to 0.994 ) with most of them using dorsum and neck regions (Table 2, Fig. 2). 


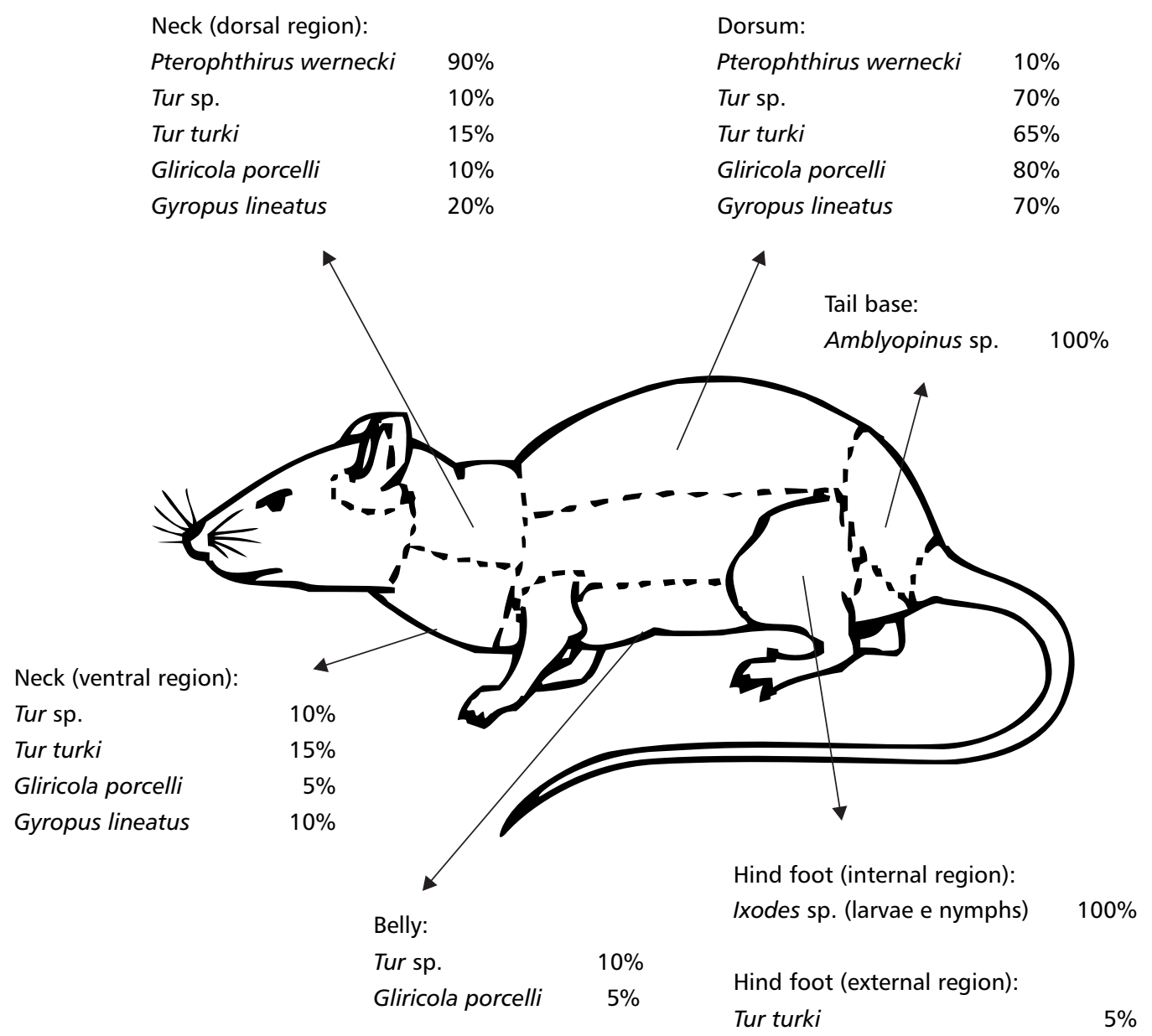

Fig. 2 - Sites on the body of Proechmys iheringi occupied by different species of ectoparasites and Amblyopinus sp., and their respective occurrence densities (as percentages of the estimated total) in the Atlantic Rainforest area of Ilha Grande.

TABLE 2

Niche overlap values between different ectoparasite species and the Amblyopinini Amblyopinus sp. on the rodent host Proechimys iheringi in the Atlantic Rainforest of Ilha Grande.

\begin{tabular}{|c|c|c|c|c|c|c|}
\hline & Ixodes sp. & Tur sp. & Tur turki & $\begin{array}{l}\text { Gliricola } \\
\text { procelli }\end{array}$ & $\begin{array}{l}\text { Gyropus } \\
\text { lineatus }\end{array}$ & $\begin{array}{l}\text { Pterophthirus } \\
\text { wernecki }\end{array}$ \\
\hline Tur sp. & 0 & & & & & \\
\hline Tur turki & 0 & 0.981 & & & & \\
\hline Gliricola porcelli & 0 & 0.994 & 0.978 & & & \\
\hline Gyropus lineatus & 0 & 0.981 & 0.992 & 0.984 & & \\
\hline Pterophthirus wernecki & 0 & 0.245 & 0.322 & 0.232 & 0.376 & \\
\hline Amblyopinus sp. & 0 & 0 & 0 & 0 & 0 & 0 \\
\hline
\end{tabular}


The louse $P$. wernecki showed an lower niche overlap value $\left(O_{j k}\right.$ varied from 0.232 to 0.376) (Table 2).

On Sciurus aestuans, only one tick species was found (larvae of Amblyomma sp. Koch, 1844 Ixodidae: Parasitiformes) which occurred only on the ear border of the hosts. Similarly, on Oxymycterus sp. only one amblyopine species (Amblyopinodes sp.) was found, restricted to the dorsal base of the host tail. On Nectomys squamipes we found only the mite Gigantolaelaps goyanensis Fonseca, 1939 (Laelapidae: Parasitiformes) which occurred on dorsum and head (usually found on the orbital region, attached to the eyelid) but could move between these body regions.

\section{DISCUSSION}

The data showed that some of the arthropods are relatively specific to rodent body regions (narrow spatial niche breadth) whereas others are distributed over a large number of sites (wide niche breadth). In general, only the ticks (Ixodes sp. and Amblyomma sp.) and the beetles (Amblyopinini) showed specificity for certain regions. The values of the spatial niche breadth of the ectoparasites and Amblyopinini were usually low, indicating that preferred sites are relatively limited. Information on preferred sites on a rodent host body by ectoparasites are available only in studies by Castro et al. $(1990,1995,1996 a, 1996 b)$ and Cicchino \& Castro (1994) who showed that some lice species (Anoplura and Mallophaga) have specific oviposition sites on their hosts. Our data also indicatives that some ectoparasites and Amblyopinini occur only on certain sites on the host. Site preference may be due to easier food (body fluid and tissue) access or to avoid host removal. However, the reasons underlying the preferred sites for each species deserve further study. The data also suggest that some ectoparasites may greattly overlap in the use of particular sites on the same host which explains their to occurrence on the same regions of the host. We believe that this may simply bethe result of the host's inabilety to access these sites, since those occupied by the ectoparasites were commonly most inaccessible and, therefore, the safest. Conversely, in the cases of the ticks and Amblyopine, this explanation seems insufficient because these groups are specific to sites relatively accessible to the host.
In the case of the ticks (Ixodes sp.), their occurrence on the internal surface of the host thigh (supposedly a place of easy removal) may be due to the high attachment capability of the ticks, which use specialized mouthparts (hypostome) not only to perforate the skin and feed but also to remain very strongly attached to the host body. In the field, we frequently found these ticks attached to the host body only by the hypostome without even using the legs to grasp hair, which indicates how difficult they are to remove.

We occasionally observed efforts of the host to remove the ticks by scratching, which resulted in hair loss, and epidermic injuries (pers. obs.). We therefore believe that the occurrence of ticks on an site easily accessible results from their secure attachment to the host body. In the case of the Amblyopinini, the occurrence of these species on sites easily accessible may be because these insects are not ectoparasites. Some studies have shown that these insects may move freely on the host body (including on easily reached regions), and hypothesized that the relationship could actually be mutualistic (Ashe \& Timm, 1987a, 1987b; Timm \& Ashe, 1988). It has been suggested that the Amblyopinini may actually act as ectoparasite-predators on the host body and in the nest (Ashe \& Timm, 1987a).

We conclude that the ectoparasites and Amblyopinini we found living on some rodent hosts at Ilha Grande tend to show a preference for some sites on the host body, and that some ectoparasite species may overlap, largely on sites of the difficult access to the host which increases the chance of their occurrence there.

Acknowledgments - This study was made as part of the Ecology, Conservation, and Management Program of Southeastern Brazilian Ecosystems and of the Southeastern Brazilian Vertebrate Project (Vertebrate Ecology Laboratory), both of the Setor de Ecologia, Instituto de Biologia Roberto Alcântara Gomes, Universidade do Estado do Rio de Janeiro. We would like to thank the specialists who helped us identify the ectoparasites and the small mammal mites: Dr. D. Gettinger of the University of Central Arkansas; ticks: Dr. G. S. Gazêta, Dra. M. Amorim, and Dr. N. M. Serra-Freire, all of the Laboratório de Ixodides of Fundação Oswaldo Cruz (FIOCRUZ); lice: Dr. P. B. Ribeiro of the Departamento de Microbiologia e Parasitologia of the UFPel; beetles: Dr. L. G. Santos Neto of the Dept. de Entomologia of UFPR; Proechimys iheringi: Dra. L. Pessôa Departamento de Zoologia UFRJ; and the other mammals: Dra. L. Geise of the Setor de Zoologia UERJ. We also thank D. Gettinger, H. G. Bergallo, L. Geise, M. Van Sluys, and M. A. S. Alves for suggestions on a previous version of 
the study. E. B. Bittencourt thanks Coordenação de Aperfeiçoamento de Pessoal de Nível Superior (CAPES) for a Graduate Fellowship, and C. F. D. Rocha for a Research Grant from Conselho Nacional do Desenvolvimento Científico e Tecnológico (CNPq) (Process 300 814/94-3).

\section{REFERENCES}

ARAUJO, D. S. D. \& OLIVEIRA, R. R., 1988, Reserva Biológica Estadual da Praia do Sul (Ilha Grande, Estado do Rio de Janeiro): Lista preliminar da flora. Acta. Bot. Bras., 1(2): 83-94.

ASHE, J. S. \& TIMM, R. M., 1987a, Predation by and activity patterns of 'parasitic' beetles of the genus Amblyopinus (Coleoptera: Staphylinidae). J. Zool., 212: 429-437.

ASHE, J. S. \& TIMM, R. M., 1987b, Probable mutualistic association between staphylinid beetle (Amblyopinus) and their rodent host. J. Trop. Ecol., 3: 177-181.

BERGALLO, H. G., 1995, Os efeitos da disponibilidade de alimentos e dos fatores climáticos na reprodução, condição, crescimento e uso do espaço por quatro espécies de roedores no Sudeste do Brasil. Tese de Doutorado, Unicamp, Campinas, Brasil, 130p.

CASTRO, D. C., CICCHINO, A. C., GONZALEZ, A. \& MACHEL, E. M., 1996a, Una nueva especie del género Hoplopleura Enderlein, 1904 (Phthiraptera, Hoplopleuridae), parásito de Chelemys macronyx vestitus (Thomas, 1903) (Rodentia, Cricetidae). Revta. Bras. Ent., 40(2): 159-164.

CASTRO, D. C., CICCHINO, A. C. \& LARESCHI, M., 1996b, Morfología coriónica de los huevos de Phrhiraptera (Psocodea) parásitos de Cavia pamparum Thomas, 1917 (Rodentia, Caviidae). Revta. Bras. Ent., 40(2): 211-220.

CASTRO, D. C., CICCHINO, A. C. \& VILlalobOS, L. C., 1990, Contribución al conocimiento de Hoplopleura reducta Ferris, 1921 (Phthiraptera, Anoplura, Hoplopleuridae). Revta. Bras. Ent., 34(4): 801-806.

CASTRO, D. C., GONZALEZ, A. \& CICCHINO, A. C., 1995, Una nueva especie del género Hoplopleura Enderlein, 1904 (Phthiraptera, Hoplopleuridae), ectoparásito de Neotomys ebriosus vulturnus Thomas, 1921 (Rodentia, Cricetidae). Revta. Bras. Ent., 39(4): 839-848.
CICCHINO, A. C. \& CASTRO, D. C., 1994, On Gyropus parvus parvus (Ewing, 1924) and Phtheiropoios rionegrensis sp. n. (Phthiraptera, Amblycera, Gyropidae), parasitic on Ctenomys haigi Thomas, 1919 (Mammalia, Rodentia, Ctenomyidae). IHERINGIA, Sér. Zool., 77: 3-14.

GUIMARÃES, J. H. \& PAPAVERO, N., 1999, Myiasis in man and animals in the neotropical region. Editora Plêiade, Fund. Amparo à Pesquisa do Estado de São Paulo - FAPESP, São Paulo, 308p.

MAcARTHUR, R. H. \& LEVINS, R., 1967, The limiting similarity, convergence and divergence of coexisting species. Amer. Natur., 101: 377-385.

MARSHALL, A. G., 1981, The ecology of ectoparasitic insects. Academic Press, London, 459p.

PEREIRA, L. A., 1994, Ecologia de mamíferos da Mata Atlântica: parasitismo de Metacuterebra spp. (Diptera Cuterebridae) em cinco espécies de pequenos mamíferos da Reserva Biológica de Poço das Antas (Mun. Silva Jardim, Rio de Janeiro). Floresta e Ambiente, 1: 86-90.

PIANKA, E. R., 1973, The structure of lizards communites. Ann. Rev. Ecol. Syst., 4: 53-74.

PIANKA, E. R., 1986, Ecology and natural history of desert lizards. Princeton Univ., Princeton, New Jersey, 208p.

SERRA-FREIRE, N. M., CAVALCANTI, P. L., GAZETA, G. S., NOGUEIRA, E. O., ROCHA, G. C. \& MADURO, C. H., 1995, Ecto- e entero-parasitos de bovinos Jersey em Resende, Estado do Rio de Janeiro, Brasil. Rev. Univ. Rural, Sér. Ciênc. da Vida, 17(1): 75-81.

SERRA-FREIRE, N. M. \& CUNHA, D. W., 1987, Amblyomma cajennense comportamento de ninfas e adultos como parasitos de bovinos. Rev. Bras. Med. Vet., 9(5): 100-103.

SIMPSON, E. H., 1949, Measurement of diversity. Nature, 163: 688 .

TIMM, R. M. \& ASHE, J. S., 1988, The mystery of the gracious host. Natural History, 9: 6-9. 